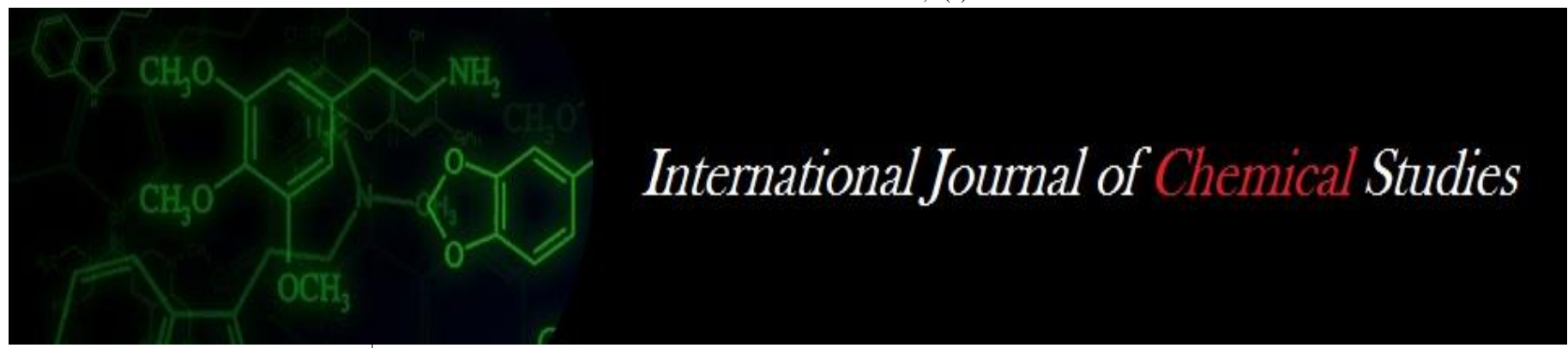

P-ISSN: 2349-8528

E-ISSN: 2321-4902

www.chemijournal.com

IJCS 2021; 9(1): 416-422

(C) 2021 IJCS

Received: $23-10-2020$

Accepted: 03-12-2020

\section{Dulesh Sahu}

Department of Plant Pathology,

IGKV, Raipur, Chhattisgarh,

India

\section{N Lakpale}

Department of Plant Pathology, IGKV, Raipur, Chhattisgarh,

India

\section{Seed health evaluation of Different varieties of Lentil by incubation methods}

\author{
Dulesh Sahu and N Lakpale
}

DOI: https://doi.org/10.22271/chemi.2021.v9.i1f.11263

\begin{abstract}
Seeds of lentil harbour the seed borne mycoflora which adversely affect the germination and seedling vigour. Five varieties of lentil and one local variety were taken in the present investigation to assess the seed health by incubation methods. In this study, varying degree and types of mycoflora associated with lentil seeds were recorded. The mycoflora recorded were Aspergillus flavus, Aspergillus niger, Penicillium sp., Trichoderma sp., Nigrospora sp., Chaetomium globosum, Alternaria alternata, Curvularia lunata, Fusarium sp., and Rhizopus stolonifer. In most of the methods, poor germination was observed in local variety, may be due to presence of seed associated mycoflora with higher frequencies whereas JL-3 variety has higher germination due to lower frequencies of detected mycoflora as compared to other varieties of lentil taken in the study.
\end{abstract}

Keywords: Lentil, seed borne mycoflora, seed health

\section{Introduction}

The word lentil is derived from 'Latin' word "lens". Lentil (Lens culinaris Medik.) is the most ancient cultivated pulse crops among the legumes. Many common names are known as malka masoor (bold seeded), masuri (small seeded), masura and renuka. Masoor has been originated in East Mediterranean region, such as Asia Minor and Egypt. Lentil is most nutritious legume crop in India, mostly cultivated as rainfed crop during winter season after rice, maize, pearl millet or rainy fallow. Lentil is recognized one of the most nutritious legume crops ranking next to gram or chickpea amongst pulses. In lentil nutritive values are protein (24-26\%), carbohydrate $(57-60 \%)$, fat $(1.3 \%)$, fibre $(3.2 \%)$, phosphorus $(300 \mathrm{mg} / 100 \mathrm{~g})$, iron $(\mathrm{Fe})$ $(7 \mathrm{mg} / 100 \mathrm{~g})$, vitamin-C (10-15mg/100g), calcium (Ca) $(69 \mathrm{mg} / 100 \mathrm{~g})$, vitamin-A (450 IU) and calorific value $(343 \mathrm{Kcal} / 100 \mathrm{~g})$. In India, total lentil production during 2018-19, $1.53 \mathrm{mt}$ (Anon., 2019) ${ }^{[7]}$.

Healthy seeds are the basis of healthy plants or crop, an important condition for good yield or outputs (Diaz et al. 1998) ${ }^{[13]}$. Diseases are main constraint in economically crop production as they cause heavy losses. The crop is affected by wide range of fungal diseases viz., botrytis grey mould (Botrytis fabae and B. cinerea), lentil rust (Uromyces viciae-fabea), stemphylium blight (Stemphylium botryosum), anthracnose (Colletotrichum truncatum), fusarium wilt (Fusarium oxysporum f.sp. lentis) and collar rot (Sclerotium rolfsii). Masur (lentil) can be also contaminated by a wide range of viruses but mostly affect on yield is not as major as that caused by fungal microbes or pathogens. Masur (lentil) yellow disease caused by (BLRV) bean leaf roll virus, (BWYV) beet western yellows virus or (SCRLV) subterranean clover red leaf virus and (PSdMV) pea seed borne mosaic (Taylor et al., 2007) ${ }^{\text {[51] }}$. Mostly fungal flora associated with seeds at the stage of harvesting, transporting, processing and under storage bring about certain undesirable changes, making them unfit for human consumption and sowing purpose. Presence or absence of seed borne pathogens on the seed coat or surface is significant aspect that determine the good quality of seed.

Till date, seed health evaluation aspects like mycoflora associated, their effect on germination of seedling vigour index and management not studied well and documented for different lentil varieties of Chhattisgarh. Therefore, an attempt is taken in the present investigation entitled seed health evaluation of different varieties of lentil (Lens culinaris M.) by incubation methods.
Corresponding Author:

Dulesh Sahu

Department of Plant Pathology,

IGKV, Raipur, Chhattisgarh,

India 


\section{Methods and Materials}

Unless and otherwise mentioned for each experiment, In each plates, ten seeds were placed on moist blotter paper in such a way that nine seeds formed the periphery of petri plate and one at the centre of petri plate. For each seed samples, 20 replicated plates were maintained (total of 200 seeds tested for each seed samples). Incubated the seeded plates at $25 \pm 1{ }^{\circ} \mathrm{C}$ for seven days in alternating cycles of 12 hours darkness and 12 hours light in NUV. Observations were recorded as explained earlier. All seeds of the periphery of plate were examined first, then finally seed in the centre of petri plate and expressed in percentage of seed associated mycoflora, individually.The organisms were observed under the stereobinocular microscope on seeds for their habit characters and confirmed under compound microscope.

The associated fungal flora were identified with the help of standard literature like Illustrated Genera of Imperfect Fungi (H.L. Barnett, 1962) ${ }^{[8]}$, More Dematiaceous Hypomycetes (M.B. Ellis, 1976) and A Pictorial Guide to the Identification of Seed borne Fungi of Sorghum, Pearl Millet, Finger Millet, Chickpea, Pigeonpea and Groundnut (ICRISAT, 1978). Several methods of seed health testing have been developed for the detection of fungi associated with seeds. Some of the most suitable procedures have been recommended by the International Seed Testing Association (ISTA) (Anon., 1966). The following standard methods recommended were used in the present study for seed health evaluation of different varieties of pea.

1. Standard blotter method (ISTA, 1976) ${ }^{[20]}$.

2. Agar plate method (Muskett and Malone, 1941) ${ }^{[35]}$.

3. Roll paper towel method (Yaklich, 1985) ${ }^{[53]}$

4. Deep freeze method (Limonard, 1968) ${ }^{[32]}$.

\section{Standard blotter method}

In standard blotter method, the fast growing fungi were better detected than the slow growing ones. In each sterilized interfitting plastic petri plates, two good quality sterilized blotter paper of the same diameter were kept and moist with sterilized distilled water. In each plates, ten seeds were placed on moist blotter paper in such a way that nine seeds formed the periphery of petri plate and one at the centre of petri plate. For each seed samples, 20 replicated plates were maintained (total of 200 seeds tested for each seed samples). Incubated the seeded plates at $25 \pm 1^{\circ} \mathrm{C}$ for seven days in alternating cycles of 12 hours darkness and 12 hours light in NUV. Observations were recorded as explained earlier. All seeds of the periphery of plate were examined first, then finally seed in the centre of petri plate and expressed in percentage of seed associated mycoflora, individually.

The frequency of the mycoflora was calculated by the following formula

\section{No. of seeds containing a particular fungus}

Total seeds examined

\section{Agar plate method}

Potato dextrose agar (PDA) media $(15-20 \mathrm{ml})$ was poured in each sterilized petri plates. A little amount of Streptomycin sulphate was added in the media at the time of pouring to avoid the bacterial contaminations. Seeds of each variety were surface sterilized with $1.0 \% \mathrm{NaOCl}$ solution for 30 seconds and immediately washed twice with sterile distilled water thoroughly to remove $\mathrm{NaOCl}$ solution adhered, if any. Seed were placed on the previously poured PDA medium in petri plate in such a manner that nine seeds in periphery and one at centre of petri plate. For each seed sample, 20 replicated plates were maintained and incubated at $25 \pm 1^{\circ} \mathrm{C}$ under alternate cycles of 12 hours dark and 12 hours light in NUV. Obsevations were recorded as described earlier.

\section{Roll paper towel method}

The seeds (50) were placed on moist paper towel at equidistance and covered with the another moist paper towel and rolled carefully without disturbing already arranged seeds. Tie the towel with help of rubber band at both side ends. To avoid the water loss, polythene or wax coated paper used for wrapping the rolled paper towels containing seeds. Incubate it for 4 to 5 days at room temperature. Examine the normal and abnormal seedlings, cause of abnormalities, failure in germination and ungerminated seeds by naked eyes and presence of different mycoflora by stereoscopic binocular microscope. The observations were recorded for different catagories were-

Normal seedlings - show the potential for continued growth and development into the satisfactory plants when grown in good quality soil and under favorable conditions of temperature, light and moisture.

\section{Categories}

1. Intact seedlings: Seedlings with all their essential structure, well developed, complete in proportion and healthy.

2. Seedlings with slight defect: Seedlings showing slight defect of their essential structure provided they show a satisfactory and balanced development comparable to that of intact seedlings of the same test.

3. Seedlings with secondary infection: Seedlings as described above but have been affected by fungi or bacteria.

Abnormal seedlings: Do not show the potential to develop into a plant when grown in good quality soil and under favorable condition of moisture, temperature and light.

\section{Categories}

1. Damaged: Seedlings with any of essential structure missing or badly and irrepairably damaged and balance development cannot be expected.

2. Deformed or unbalanced: Seedlings with weak development or physiological disturbance or in which essential structures are deformed or out in proportion.

3. Decayed: Seedlings with any of their essential structure so diseased or decayed as a result of primary infection that normal development is prevented.

Ungerminated seeds: Did not germinated at the end of the test period.

1. Hard seeds: Seeds which have not absorbed water thus remain hard after end of the test period.

2. Fresh seeds: Seeds able to imbibe water but which failed to germinate under condition of the germination test remains clean and firm and have the potential to develop into the normal seedling.

3. Dead seeds: Seeds at the end of the test period are neither hard nor fresh, failed to produce a seedling; usually soft, discolored, frequently moldy. 
Other - empty, embryo less seeds, intact damaged seeds.

\section{Deep freeze method}

It was a modification of standard blotter method. The seeds were placed on blotter papers moistened with a solution containing $0.2 \%$ Streptopenicillin (to avoid bacterial contamination) and incubated for $24 \mathrm{hrs}$. under normal conditions in growth chamber. Plates were further incubated at $10 \pm 1^{\circ} \mathrm{C}$ for three days and then transferred to the deep freezer $\left(-20^{\circ} \mathrm{C}\right)$ under complete darkness for $24 \mathrm{hrs}$. Plates were again incubated at 20-25 $\pm 1{ }^{\circ} \mathrm{C}$ for 5-7 days. Observations were recorded as described earlier.

\section{Result and Discussion \\ Standard blotter method}

Seed lots of different varieties of lentil were evaluated for the seed associated mycoflora by using standard blotter method and data presented in the table 1 showed that the seed lot of local variety were found maximum frequency of mycoflora $(129.99 \%)$ with minimum germination percentage $(80.00 \%)$. Mycoflora were detected as Aspergillus flavus $(30.00 \%)$, Chaetomium globosum (30.00\%), Fusarium sp. (30.00\%), Rhizopus stolonifer (23.33\%), A. niger (13.33\%) and Alternaria alternata (3.33\%). This was followed by IPL-81 variety $(116.65 \%)$ with germination percentage $(90.00 \%)$ and detected mycoflora were as Aspergillus flavus (30.00\%), Fusarium sp. (26.66\%), Rhizopus stolonifer (23.33\%), Chaetomium globosum (20.00\%), A. niger (13.33\%) and Penicillium sp. (3.33\%).

In the seed lot of varieties L-4076, DPL-62, K-75 and JL-3, frequency of associated mycoflora were (106.64\%), $(103.32 \%),(103.30 \%)$ and $(99.99 \%)$, respectively. In JL-3 variety, minimum frequency of mycoflora $(99.99 \%)$ includes Fusarium sp. (26.66\%), Aspergillus flavus (20.00\%), Rhizopus stolonifer (20.00\%), Chaetomium globosum (20.00\%) and Aspergillus niger (13.33\%) with maximum germination percentage $(96.66 \%)$. In variety K-75, frequency of associated mycoflora namely Aspergillus flavus (26.66\%), Chaetomium globosum (23.33\%), Rhizopus stolonifer (16.66\%), Fusarium sp. (16.66\%), A. niger (10.00\%), Penicillium sp. $(6.66 \%)$ and Alternaria alternata $(3.33 \%)$ with germination percentage $(93.33 \%)$ were recorded. In variety DPL-62, frequency of associated seed borne mycoflora recorded as Aspergillus flavus (30.00\%), Fusarium sp. (26.66\%), Rhizopus stolonifer (20.00\%), Chaetomium globosum (16.66\%) and Aspergillus niger (10.00\%) with germination percentage $(96.66 \%)$. In variety L-4076, frequency of mycoflora (106.64\%) includes Fusarium sp. (26.66\%), Chaetomium globosum (23.33\%), Aspergillus flavus (20.00\%), Rhizopus stolonifer (16.66\%), Aspergillus niger (13.33\%), Nigrospora sp. (3.33\%) and Alternaria alternata $(3.33 \%)$. Nigrospora sp. found only in L-4076 variety.

The relative abundance of mycoflora Aspergillus flavus $(142.40 \%)$ were found maximum from seed lost of lentil. Other predominated mycoflora were Fusarium sp. (139.53\%), Chaetomium globosum (120.81\%), Rhizopus stolonifer (109.06\%), A. niger (66.87\%), Penicillium sp. (9.30\%), Alternaria alternata (8.90\%) and Nigrospora sp. (3.12\%).

In this method, local variety shows maximum frequency $(129.99 \%)$ of mycoflora with minimum germination percentage while lowest frequency $(99.99 \%)$ of mycoflora were observed in JL-3 variety among all the varieties of lentil taken in the study. Lentil varieties recorded Aspergillus flavus
(156.66\%) in highest frequency and Nigrospora sp. (3.33\%) in lowest frequency.

Present finding are in agreement of finding of El-Nagerabi and Elshafie (2000) [14], Allah and Hashem (2006) [4], Husasain et al. (2007) [19], Kayata and Agrawal (2010) [26] Hoque et al. (2014) ${ }^{[18]}$, Mahal (2014) ${ }^{[33]}$ and Lambat et al. (2015) ${ }^{[31]}$ as they reported almost similar results for the seed associated mycoflora detected from seeds of lentil by using standard blotter paper method. Javaid et al. (2005) [21], Embaby and Abdel-Gail (2006) [15], Abdullah (2008) [1], Agrawal et al. (2011) ${ }^{[2]}$, Rathod et al. (2012) ${ }^{[44]}$, Ghangaoker and Kshirsagar (2013) [17], Narayan and Ayodhya (2013) ${ }^{[36]}$, Embaby et al. (2013) ${ }^{[16]}$, Pradhan (2017), Kumar et al. (2017) ${ }^{[28]}$, Kawale et al. (2018) ${ }^{[25]}$, Parashar et al. (2019) ${ }^{[38]}$ and Kandhare (2020) ${ }^{[24]}$ in legumes (green gram, black gram, chickpea and pigeonpea) reported the almost similar results for detected seed associated mycoflora by using the standard blotter paper method. Rahman et al. (1999) ${ }^{[43]}$ in mungbean and black gram; Barua et al. (2007) [9], Patil et al. (2012) ${ }^{[37]}$ and Sadhu (2014) ${ }^{[47]}$ examined the different varieties of green gram by using standard blotter paper method and reported almost similar results. Sharma (2002) ${ }^{[48]}$, Kumar et al. (2017) ${ }^{[28]}$ and Kesharwani et al. (2018) ${ }^{[27]}$ in pea; Raddy et al. (2006) [46], Pradhan et al. (2015) ${ }^{[39]}$ and Chaudhari et al. (2016) ${ }^{[10]}$ in pigeonpea; Dawar et al. (2007) ${ }^{[12]}$, Razia and Pathak (2013) [45], Sontakke and Hedawoo (2014) [50], Chougule et al. (2015) [11], Warude (2016) ${ }^{[52]}$, Amule et al. (2019) and Javid and Khan (2019) reported the results in different chickpea varieties and detected the seed associated mycoflora by using standard blotter paper method. Milad and Milad (2017) ${ }^{[34]}$ in broad bean; Kumari and Saxena (2017) ${ }^{[29,}$ ${ }^{30]}$ and Pradhan (2019) ${ }^{[40]}$ in Indian bean; Zanjare et al. (2020) [54] in cowpea evaluated seed health by using blotter paper method and reported common seed associated mycoflora supports too findings of present study.

\section{Agar plate method}

Seeds of six varieties of lentil were evaluated for the associated seed borne mycoflora by agar plate method and the data presented in table 2. Maximum frequency of mycoflora were recorded from seeds of local variety $(143.31 \%)$ which include Aspergillus flavus (30.00\%), Fusarium sp. (30.00\%), Rhizopus stolonifer (26.66\%), Chaetomium globosum (23.33\%), A. niger (20.00\%), Penicillium sp. (6.66\%) and Alternaria alternata $(6.66 \%)$ with minimum germination percentage $(70 \%)$ followed by IPL-81 seed lot mycoflora (139.99\%) with germination percentage (76.66\%). Frequencies of mycoflora recorded from the seeds of other varieties of lentil L-4076 (133.31\%), K-75 (129.98\%), DPL$62(126.64 \%)$ and least in JL-3 (109.98\%) with varying germination percentage as $76.66,80.00,83.33$ and 86.66, respectively.

Different mycoflora were detected from lentil varieties by this method, in which Aspergillus flavus (169.98\%) was recorded maximum and it was most frequent in local variety, L-4076 and IPL-81 $(30.00 \%)$. This was followed by Rhizopus stolonifer (166.65\%), Fusarium sp. (163.32\%), Chaetomium globosum (129.97\%), A. niger (103.31\%), Curvularia lunata (36.66\%). Penicillium sp. (6.66\%) and Alternaria alternata $(6.66 \%)$ was found least in lentil varieties.

The relative abundance of Aspergillus flavus (130.67\%) was found maximum from seed lot of lentil. Other predominated mycoflora were Rhizopus stolonifer (128.94\%), Fusarium sp. (123.78\%), Chaetomium globosum (99.26\%), A. niger 
(82.71\%), Curvularia lunata (28.87\%). Penicillium sp. $(4.18 \%)$ and Alternaria alternata $(4.18 \%)$ was found least in relative abundance in lentil varieties.

Kaiser (1992) ${ }^{[23]}$, Saheb et al. (2016) and Parashar et al. (2019) ${ }^{[38]}$ in legumes (chickpea, mung, pigeonpea and lentil) detected and identified seed associated mycoflora by using agar plate method. Rathod et al. (2012) ${ }^{[44]}$, Al- Tarjuman and Ramdan (2017) ${ }^{[5]}$ and Kawale et al. (2018) ${ }^{[25]}$ in different legume seeds (Pea, black gram, green gram and pigeonpea) recorded common seed borne mycoflora. Ali et al. (2010) ${ }^{[3]}$, Sadhu (2014) ${ }^{\text {[47] }}$ and Pradhan (2017) in mungbean seeds; Patil et al. (2012) ${ }^{[37]}$, Pradhan et al. (2015) ${ }^{[39]}$ and Chaudhari et al. (2016) [10] detected seed associated mycoflora in different varieties of pigeonpea. Sontakke and Hedawoo (2014) ${ }^{[50]}$, Trivedi and Rathi (2015), Warude et al. (2010) and Amule et al. (2019) tested various varieties of chickpea and reported almost similar results for seed associated mycoflora. Kumar et al. (2017) ${ }^{[28]}$ and Kesharwani et al. (2018) ${ }^{[27]}$ in pea varieties; Kumari and Saxena (2017) ${ }^{[29,30]}$ in horsegram; Pradhan (2017) in mungbean; Kumari and Saxena (2017) and Pradhan (2019) ${ }^{[40]}$ in Indian bean and Zanjare et al. (2020) ${ }^{[54]}$ in cowpea reported seed borne mycoflora when evaluated by agar plate method. Findings of present study is in corroboration with the findings of above researchers as for as seed borne mycoflora is concern.

\section{Rolled paper towel method}

Seed lot of six varieties of lentil were examined for associated seed borne mycoflora in varying frequency with normal seedling, abnormal seedling and ungerminated seeds by roll paper towel method. It was observed that presence of mycoflora may be the cause of abnormalities and failure in seed germination. In this method, mycoflora were detected associated with seed and seedling of different lentil varieties. Maximum frequency of mycoflora were observed from local variety $(110.00 \%)$ and mycoflora detected were Aspergillus flavus $(26.00 \%)$, Fusarium sp. (24.00\%), Rhizopus stolonifer and Penicillium sp. (18.00\%), Chaetomium globosum (12.00\%), Aspergillus niger and Alternaria alternata $(6.00 \%)$ with minimum germination percentage $(80.00 \%)$ followed by frequency of mycoflora in varieties IPL-81 (106.00\%), K-75 (98.00\%), DPL-62 (92.00\%), L-4076 (92.00\%) and JL-3 $(82.00 \%)$ and germination percentage recorded in all these different lentil varieties were 80.00, 86.00, 90.00, 88.00 and 92.00 , respectively.

In seeds of IPL-81 variety, mycoflora were recorded as Aspergillus flavus and Fusarium sp. (24.00\%), Rhizopus stolonifer (18.00\%), Chaetomium globosum (16.00\%), T. viride (14.00\%), Aspergillus niger $(6.00 \%)$ and Penicillium sp. $(4.00 \%)$. In K-75 variety, associated mycoflora were Fusarium sp. (24.00\%), Aspergillus flavus and Rhizopus stolonifer (16.00\%), Trichoderma viride (14.00\%), Aspergillus niger and Chaetomium globosum (10.00\%) and Penicillium sp. (8.00\%). Mycoflora detected in DPL-62 variety were Fusarium sp. (20.00\%), Aspergillus flavus (16.00\%), Rhizopus stolonifer (14.00\%), Trichoderma viride (14.00\%), Chaetomium globosum and Aspergillus niger (10.00\%) and Penicillium sp. (8.00\%). In L-4076 variety, mycoflora detected were Aspergillus flavus and Fusarium sp. (24.00\%), Chaetomium globosum (18.00\%), Rhizopus stolonifer (10.00\%), Penicillium sp. (8.00\%), Aspergillus niger and Alternaria alternata (4.00\%). In JL-3 variety, showed least frequency of mycoflora $(82.00 \%)$ includes Aspergillus flavus and Chaetomium globosum (18.00\%),
Fusarium sp. (18.00\%), Rhizopus stolonifer and Trichoderma viride (12.00\%) and Aspergillus niger (4.00\%).

Relative abundance of mycoflora were Fusarium sp. (138.71\%) followed by Aspergillus flavus (128.03\%), Rhizopus stolonifer (90.40\%), Chaetomium globosum (88.58\%), Trichoderma viride (57.35\%), Penicillium sp. (45.67\%), Aspergillus niger $(41.42 \%)$ and Alternaria alternata $(9.80 \%)$.

Singh et al. (2014) recorded that the mycoflora and germination percentage of seeds (rice, wheat, pigeonpea and gram) and Sontake and Hedawoo (2014) in chickpea. Pradhan et al. (2015) ${ }^{[39]}$ recorded commonly occurring seed borne mycoflora associated with seeds in pigeonpea by roll towel method namely as Aspergillus flavus, A. fumigatus, A. niger, Penicillium sp. and Mucor sp. Kesharwani et al. (2018) recorded seed associated fungal flora in different pea varieties as Aspergillus flavus, A. niger, A. fumigatus, Trichoderma sp., Alternaria sp., Curvularia sp., Chaetomium sp. and Rhizopus sp. by roll paper towel method. Amule et al. (2019) in chickpea; Pradhan and Lakpale (2020) [41] in different varieties of Indian bean seed observed different seed borne mycoflora by using roll paper towel method as Aspergillus flavus, A. fumigatus, A. terreus, Curvularia lunata, Alternaria alternata and Fusarium sp. Findings of present investigation are in agreement with the findings of earlier researchers that most of the common fungi in varying frequencies and their impact on germination were recorded.

\section{Deep freeze method}

Seed lot of lentil varieties were tested for the associated seed borne mycoflora using deep freeze method and data presented in table 4. Frequency of mycoflora associated were maximum in local variety seed lot $(89.98 \%)$ and mycoflora detected were Aspergillus flavus (26.66\%), Fusarium sp. and Chaetomium globosum (23.33\%), Rhizopus stolonifer $(13.33 \%)$ and Alternaria alternata $(3.33 \%)$ with minimum germination $(73.33 \%)$ recorded. It was followed by L-4076 variety and IPL-81 (76.65\%), K-75 (73.31\%), DPL-62 $(69.99 \%)$ and JL-3 $(53.32 \%)$ and with the germination percentage of the lentil varieties were $76.66 \%, 80.00 \%$, $76.66 \%, 83.33 \%$ and $90.00 \%$, respectively.

Mycoflora observed in seed lot of L-4076 were Fusarium sp. (23.33\%), Aspergillus flavus (20.00\%), Chaetomium globosum (16.66\%), Rhizopus stolonifer (13.33\%) and Alternaria alternata (3.33\%). In IPL-81 variety, seed borne mycoflora were Aspergillus flavus (26.66\%), Fusarium sp. (23.33\%), Chaetomium globosum (16.66\%) and A. niger $(10.00 \%)$. Mycoflora observed in K-75 variety were Fusarium sp. (26.66\%), Aspergillus flavus (23.33\%), Chaetomium globosum (13.33\%), Rhizopus stolonifer (6.66\%) and A. niger (3.33\%). In variety DPL-62, recorded mycoflora were Aspergillus flavus (20.00\%), Fusarium sp. (20.00\%), Chaetomium globosum (16.66\%) and Rhizopus stolonifer (13.33\%). In variety JL-3, recorded mycoflora were Fusarium sp. (16.66\%), Aspergillus flavus (13.33\%), Rhizopus stolonifer $(13.33 \%)$ and Chaetomium globosum (10.00\%).

In this method, relative abundance of different mycoflora such as Fusarium sp. (182.99\%), Aspergillus flavus (175.90\%), Chaetomium globosum (130.15\%), Rhizopus stolonifer $(85.34 \%)$, A. niger $(17.26 \%)$ and Alternaria alternata $(8.04 \%)$ were recorded.

Dawar et al. (2007) ${ }^{[12]}$, Warude et al. (2016) ${ }^{[52]}$ and Amule et al. (2019) Amule et al. (2019) also recorded seed associated mycoflora in chickpea seed by deep freeze method as 
Fusarium oxysporum, Rhizoctonia bataticola, Alternaria alternata, A. flavus, A. niger, Curvularia luanata, Rhizopus sp. and Penicillium sp. Kesharwani et al. (2018) ${ }^{[27]}$ examined different pea varieties by deep freeze method and detected seed associated mycoflora as Aspergillus flavus, A. niger, Rhizopus sp., Alternaria sp. and Curvularia sp. and Pradhan
(2019) ${ }^{[40]}$ in Indian bean varieties by deep freeze method and detected associated mycoflora as Aspergillus flavus, A. niger, A. fumigatus, Alternaria atlernata, Curvularia lunata and Fusarium sp. supports the findings of above the study due to occurance of common seed borne mycoflora in various legumes.

Table 1: Detection of mycoflora associated with seeds of lentil varieties by standard blotter method

\begin{tabular}{|c|c|c|c|c|c|c|c|c|c|c|c|}
\hline \multirow[b]{2}{*}{$\begin{array}{c}\mathbf{S} . \\
\mathbf{N} .\end{array}$} & \multirow[b]{2}{*}{ Varieties } & \multirow[b]{2}{*}{$\begin{array}{c}\text { Germinat } \\
\text { ion }(\%)\end{array}$} & \multicolumn{8}{|c|}{ Frequency of mycoflora associated $(\%) /$ Relative abundance $(\%)$} & \multirow{2}{*}{$\begin{array}{c}\text { Total } \\
\text { frequn } \\
\text { cy }(\%) \\
\end{array}$} \\
\hline & & & A. flavus & A. niger & $\begin{array}{c}\text { Nigrospora } \\
\text { sp. }\end{array}$ & $\begin{array}{l}\text { Rhizopus } \\
\text { stolonifer }\end{array}$ & $\begin{array}{c}\text { Chaetomium } \\
\text { globosum }\end{array}$ & \begin{tabular}{|c|} 
Penicillium \\
sp.
\end{tabular} & Fusarium sp. & \begin{tabular}{|c|} 
Alternaria \\
alternata
\end{tabular} & \\
\hline 1 & DPL-62 & 96.66 & $30.00 *(29.04)$ & $10.00(9.68)$ & - & $20.00(19.36)$ & $16.66(16.13)$ & $\begin{array}{l}- \\
\end{array}$ & $26.66(25.81)$ & - & 103.32 \\
\hline 2 & IPL-81 & 90.00 & $30.00(25.72)$ & $13.33(11.43)$ & - & $23.33(20.00)$ & $20.00(17.15)$ & $3.33(2.85)$ & $26.66(22.85)$ & - & 116.65 \\
\hline 3 & JL-3 & 96.66 & $20.00(20.00)$ & $13.33(13.33)$ & - & $20.00(20.00)$ & $20.00(20.00)$ & 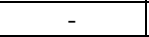 & $26.66(26.66)$ & - & \begin{tabular}{|l|}
99.99 \\
\end{tabular} \\
\hline 4 & $\mathrm{~K}-75$ & 93.33 & $26.66(25.81)$ & $10.00(9.68)$ & - & $16.66(16.13)$ & $23.33(22.58)$ & $6.66(6.45)$ & $16.66(16.13)$ & $3.33(3.22)$ & 103.30 \\
\hline 5 & L-4076 & 90.00 & $20.00(18.75)$ & $13.33(12.50)$ & \begin{tabular}{|l|}
$3.33(3.12)$ \\
\end{tabular} & $16.66(15.62)$ & $23.33(21.87)$ & - & $26.66(25.00)$ & \begin{tabular}{|l|}
$3.33(3.12)$ \\
\end{tabular} & 106.64 \\
\hline 6 & Local variety & 80.00 & $30.00(23.08)$ & $13.33(10.25)$ & - & $23.33(17.95)$ & $30.00(23.08)$ & - & $30.00(23.08)$ & $3.33(2.56)$ & 129.99 \\
\hline \multicolumn{3}{|c|}{ Total mycoflora (\%) } & $156.66(142.40)$ & $73.32(66.87)$ & $3.33(3.12)$ & 119.98 (109.06) & $133.32(120.81)$ & \begin{tabular}{|l|}
$9.99(9.30)$ \\
\end{tabular} & $153.30(139.53)$ & $9.99(8.90)$ & \\
\hline
\end{tabular}

Table 2: Detection of mycoflora associated with seeds of lentil varieties by agar plate method

\begin{tabular}{|c|c|c|c|c|c|c|c|c|c|c|c|}
\hline \multirow{2}{*}{$\begin{array}{l}\text { S. } \\
\text { N. }\end{array}$} & \multirow{2}{*}{ Varieties } & \multirow{2}{*}{$\begin{array}{c}\text { Germinat } \\
\text { ion }(\%)\end{array}$} & \multicolumn{8}{|c|}{ Frequency of mycoflora associated $(\%) /$ Relative abundance $(\%)$} & \multirow{2}{*}{$\begin{array}{c}\begin{array}{c}\text { Total } \\
\text { freque } \\
\text { ncy }\end{array} \\
(\%)\end{array}$} \\
\hline & & & A. flavus & A. niger & Fusarium sp. & $\begin{array}{c}\text { Chaetomium } \\
\text { globosum }\end{array}$ & $\begin{array}{c}\text { Penicilliu } \\
m \text { sp. }\end{array}$ & $\begin{array}{l}\text { Rhizopus } \\
\text { stolonifer }\end{array}$ & $\begin{array}{c}\text { Curvularia } \\
\text { lunata }\end{array}$ & $\begin{array}{c}\text { Alternaria } \\
\text { alternata }\end{array}$ & \\
\hline 1 & DPL-62 & 83.33 & $26.66 *(21.05)$ & $16.66(13.15)$ & $30.00(23.69)$ & $26.66(21.05)$ & - & $26.66(21.05)$ & - & - & 126.64 \\
\hline 2 & IPL-81 & 76.66 & $30.00(21.43)$ & $23.33(21.21)$ & \begin{tabular}{|l|}
$30.00(21.43)$ \\
\end{tabular} & $16.66(11.90)$ & - & \begin{tabular}{|l|}
$30.00(21.43)$ \\
\end{tabular} & $10.00(7.14)$ & - & 139.99 \\
\hline 3 & JL-3 & 86.66 & $26.66(24.24)$ & $10.00(9.09)$ & $16.66(15.15)$ & $16.66(15.15)$ & - & $30.00(27.27)$ & $10.00(9.09)$ & - & 109.98 \\
\hline 4 & K-75 & 80.00 & $26.66(20.51)$ & $16.66(12.82)$ & $30.00(23.08)$ & $20.00(15.38)$ & - & $30.00(23.08)$ & $6.66(5.13)$ & - & 129.98 \\
\hline 5 & L-4076 & 76.66 & $30.00(22.51)$ & $16.66(12.49)$ & $26.66(19.50)$ & $26.66(19.50)$ & - & $23.33(17.50)$ & $10.00(7.51)$ & - & 133.31 \\
\hline \multirow[t]{2}{*}{6} & Local variety & 70.00 & $30.00(20.93)$ & $20.00(13.95)$ & \begin{tabular}{|l|}
$30.00(20.93)$ \\
\end{tabular} & $23.33(16.28)$ & $6.66(4.18)$ & \begin{tabular}{|l|}
$26.66(18.61)$ \\
\end{tabular} & - & $6.66(4.18)$ & 143.31 \\
\hline & \multicolumn{2}{|c|}{ Total mycoflora (\%) } & $169.98(130.67)$ & $103.31(82.71)$ & $163.32(123.78)$ & $129.97(99.26)$ & $6.66(4.18)$ & $166.65(128.94)$ & $36.66(28.87)$ & $6.66(4.18)$ & \\
\hline
\end{tabular}

Table 3: Detection of mycoflora with seeds of lentil varieties by roll paper towel method

\begin{tabular}{|c|c|c|c|c|c|c|c|c|c|c|c|}
\hline \multirow{2}{*}{$\begin{array}{l}\text { S. } \\
\text { N. }\end{array}$} & \multirow[b]{2}{*}{ Varieties } & \multirow{2}{*}{$\begin{array}{c}\text { Germination } \\
(\%)\end{array}$} & \multicolumn{8}{|c|}{ Frequency of mycoflora associated (\%)/Relative abundance (\%) } & \multirow{2}{*}{\begin{tabular}{|c|} 
Total \\
mycoflora \\
$(\%)$
\end{tabular}} \\
\hline & & & A. flavus & A. niger & \begin{tabular}{|c|}
$\begin{array}{c}\text { Chaetomium } \\
\text { globosum }\end{array}$ \\
\end{tabular} & \begin{tabular}{|c|} 
Alternaria \\
alternata
\end{tabular} & \begin{tabular}{l|} 
Rhizopus \\
stolonifer
\end{tabular} & Fusarium sp. & T. viride & \begin{tabular}{|c|}
$\begin{array}{c}\text { Penicillium } \\
\text { sp. }\end{array}$ \\
\end{tabular} & \\
\hline 1 & DPL-62 & 90.00 & $16.00 *(17.39)$ & $10.00(10.87)$ & $10.00(10.87)$ & - & $14.00(15.22)$ & $20.00(21.74)$ & $14.00(15.22)$ & $8.00(8.69)$ & 92.00 \\
\hline 2 & IPL-81 & 80.00 & $24.00(22.64)$ & $6.00(5.66)$ & $16.00(15.09)$ & - & $18.00(16.98)$ & $24.00(22.64)$ & $14.00(13.21)$ & $4.00(3.77)$ & 106.00 \\
\hline \begin{tabular}{|l|}
3 \\
\end{tabular} & JL-3 & 92.00 & $18.00(21.95)$ & $4.00(4.88)$ & $18.00(21.95)$ & - & $12.00(14.64)$ & $18.00(21.95)$ & \begin{tabular}{|l|}
$12.00(14.64)$ \\
\end{tabular} & 1 & 82.00 \\
\hline 4 & K-75 & 86.00 & $16.00(16.33)$ & $10.00(10.21)$ & $10.00(10.21)$ & - & $16.00(16.33)$ & $24.00(24.48)$ & $14.00(14.28)$ & $8.00(8.16)$ & 98.00 \\
\hline 5 & L-4076 & 88.00 & $24.00(26.08)$ & $4.00(4.35)$ & $18.00(19.56)$ & $4.00(4.35)$ & $10.00(10.87)$ & $24.00(26.08)$ & - & $8.00(8.69)$ & 92.00 \\
\hline 6 & Local variety & 80.00 & $26.00(23.64)$ & $6.00(5.45)$ & $12.00(10.90)$ & $6.00(5.45)$ & $18.00(16.36)$ & $24.00(21.82)$ & - & $18.00(16.36)$ & 110.00 \\
\hline & Total myc & coflora $(\%)$ & $124.00(128.03)$ & $40,00(41.42)$ & $84.00(88.58)$ & $10.00(9.80)$ & $88.00(90.40)$ & $134.00(138.71)$ & $\mid 54.00(57.35)$ & $46.00(45.67)$ & \\
\hline
\end{tabular}

Table 4: Detection of mycoflora associated with seeds of lentil varieties by deep freeze method

\begin{tabular}{|c|c|c|c|c|c|c|c|c|c|}
\hline \multirow{2}{*}{$\begin{array}{l}\text { S. } \\
\text { N. }\end{array}$} & \multirow{2}{*}{ Varieties } & \multirow{2}{*}{$\begin{array}{c}\text { Germination } \\
(\%)\end{array}$} & \multicolumn{6}{|c|}{ Frequency of mycoflora associated $(\%) /$ Relative abundance $(\%)$} & \multirow{2}{*}{$\begin{array}{c}\text { Total } \\
\text { frequency }(\%)\end{array}$} \\
\hline & & & A. flavus & A. niger & Fusarium sp. & $\begin{array}{c}\text { Alternaria } \\
\text { alternata }\end{array}$ & $\begin{array}{c}\text { Chaetomium } \\
\text { globosum }\end{array}$ & $\begin{array}{l}\text { Rhizopus } \\
\text { stolonifer }\end{array}$ & \\
\hline 1 & DPL-62 & 83.33 & $20.00 *(28.57)$ & - & $20.00(28.57)$ & - & $16.66(23.81)$ & $13.33(19.05)$ & 69.99 \\
\hline 2 & IPL-81 & 80.00 & $26.66(34.78)$ & $10.00(12.72)$ & $23.33(30.44)$ & - & $16.66(21.74)$ & - & 76.65 \\
\hline 3 & JL-3 & 90.00 & $13.33(25.00)$ & - & $16.66(31.25)$ & - & $10.00(18.75)$ & $13.33(25.00)$ & 53.32 \\
\hline 4 & K-75 & 76.66 & $23.33(31.83)$ & $3.33(4.54)$ & $26.66(36.36)$ & - & $13.33(18.18)$ & $6.66(9.08)$ & 73.31 \\
\hline 5 & L-4076 & 76.66 & $20.00(26.09)$ & - & $23.33(30.44)$ & $3.33(4.34)$ & $16.66(21.74)$ & $13.33(17.39)$ & 76.65 \\
\hline \multirow[t]{2}{*}{6} & Local variety & 73.33 & $26.66(29.63)$ & - & $23.33(25.93)$ & $3.33(3.70)$ & $23.33(25.93)$ & $13.33(14.82)$ & 89.98 \\
\hline & \multicolumn{2}{|c|}{ Total mycoflora (\%) } & $129.98(175.90)$ & $13.33(17.26)$ & $133.31(182.99)$ & $6.66(8.04)$ & $96.64(130.15)$ & $59.98(85.34)$ & \\
\hline
\end{tabular}

* Relative abundance (\%)

\section{Conclusion}

The conclusion from the results of present study is as under

1. Seed health evaluation of six different varieties of lentil by using blotter paper, agar plate, rooled paper towel and deep freeze method reported common seed associated mycoflora.

2. Seed lots of six lentil varieties showed variation in frequency and types of seed borne mycoflora.
3. Mycoflora found associated with seeds of different lentil varieties were responsible for poor germination (Rolled paper towel method).

\section{References}

1. Abdullah AH. Pathological studies of fungi associated with pulse seeds during storage in Dammam providance, kingdom of Saudi Arabia. Middle East. and Russian. J of Pl. Sci. and Biotech 2008;2(2):71-77. 
2. Agarwal T, Malhotra A, Trivedi PC, Biyani M. Biocontrol potential of Gliocladium virens against fungal pathogens isolated from chickpea, lentil and black gram seeds. J Agril. Tech 2011;7(6):1833-1839.

3. Ali MZ, Khan MAA, Rahaman AKMM, Ahmed M, Ahsan AFMS. Study on seed quality and performance of some mungbean varieties in Bangladesh. Int. Expt. Agric 2010;1(2):10-15.

4. Allah Abd EF, Hashem A. Seed mycoflora of Lens esculenta and their biocontrol by chitosan. Phytoparasitica. 2006;34(2):213-218.

5. Al-Tarjuman JK, Ramadan NA. Isolation legumes seed borne and their effect in seed germination. Ind. J. Applied Sci 2017;7(7):531-534.

6. Amule R, Singh R, Gupta O, Raipuriya, Gupta PK. Study to detect seed borne mycoflora associated with chickpea (Cicer aeritinum L.) seeds. Int. J Curr. Microbiol. App. Sci 2019;8(11):424-428.

7. Anonymous. Commodity Profile for Pulses. Directorate of Economics and Statistics, Department of Agriculture $\&$ Cooperative and Department of Commerce 2019, 1-11.

8. Barnett HL. Illustrated genera of imperfect fungi. 2nd ed. Burgess Publishing Company, Minn 1962.

9. Barua JMM, Hossain AAM, Syedur R, Sahel MAT. Control of mycoflora of farmer stored seed of mung bean. Asin J Plant Science 2007;6(1):115-121.

10. Chaudhari AK, Sharma H, Jehani M, Sharma JK. Seed mycoflora associated with pigeonpea (Cajanus cajan (L.) Millsp.), their significance and the management. Journal of pure and applied microbiology 2016;11(1):567-575.

11. Chougule PM, Andoji YS, Kamble SS. Detection of seed borne mycoflora from different categories of chickpea (Cicer arietinum L.). Res. J Life Sci., Bioiformatics, Pharmaceutical and Chemical Sci 2015;1(4):203. 24546348.

12. Dawar S, Syed F, Ghaffar A. Sees borne fungi associated with chickpea in Pakistan. Pak. J. Bot 2007;39(2):637643.

13. Diaz C, Hossain M, Bose ML, Mercea S, Mew TW. Seed quality and effect on rice yield: finding from farmers participatory experiment in Central Luzon, Philippins. J. Crop. Sci 1998;23(2):111-119.

14. El-Nagerrabi SAF, Elshafie AE. Incidence of seed-borne fungi and aflatoxin in Sudanese lentil seeds. Mycopathologia 2000;149:151-156.

15. Embaby EM, Abdel-Galil MM. Seed borne fungi and mycotoxins associated with some legume seeds in Egypt. J. Applied Sci. Res 2006;2(11).

16. Embaby EM, Reda M, Abdel-Wahhab MA, Omara H, Mokabel M. Occurrence of toxigenic fungi and mycotoxins in some legume seeds. Int. J. Agril. Tech 2013;9(1):151-164.

17. Ghangaokar NM, Kshirsagar AD. Study of seed borne fungi of different legumes. An Int. Peer-reviewed J 2013;2(1):32-35.

18. Hoque MA, Ali MA, Haque Mahfuzul AHM, Mehraj H. Uddin Jamal AFM. Efficacy of some fungicides for the improvement of seed quality in lentil. Int. J. Sustain. Crop Prod 2014;9(3):22-26.

19. Hussain MA, Mukhtar T, Ul-haque MI, Kayani MZ. Mycoflora associated with lentil (Lens esculenta Moench) seeds from five localities of Punjab, Pakistan. Pak. J. Bot 2007;39(3):903-906.

20. ISTA. Seed health testing. International rules for seed testing. Seed Sci. and Technol 1976;4:31-34.
21. Javaid A, Bajwa R, Javaid A, Anjum T. Fungi associated with seeds of pulses collected from Lahore and their effect on seed germination. Mycopath. 2005;3(1-2):1316.

22. Javaid A, Khan IH. Mycoflora associated with seeds of different varieties of chickpea and its effect on germination and radical growth. Int. J. Biotech 2019;16(1):175-179.

23. Kaiser WJ. Fungi associated with the seeds of commercial lentils from the U.S. Pacific Northwest. Plant Dis 1992;76:605-610.

24. Kandhare AS. Effect of common and dominant seedborne fungi on dry weight content of pulses. Int. J. Innovative Sci., Engineering and Tech 2020;7(3):23487968.

25. Kawale MV, Borkar KM, Tagade WY. Seed borne fungi associated with some pulses from Gondia (MS). Int. J. Res. Biosci. Agri. Tech 2018;3(6):71-75.

26. Kayata R, Agrawal RD. Isolation of seed surface fungi of Lens culinaris (Medic). J Phytol. Res 2010;23(2):335337.

27. Kesharwani A, Lakpale N, Khare N, Tiwari PK. Comparative efficacy of different incubation methods in detecting seed borne mycoflora. Res. J. Agriculture Sciences 2018;9(4):883-885.

28. Kumar S, Lakpale N, Dewangan M. Seed health evaluation of various pulses by incubation methods. Int. J Curr. Microbiol. App. Sci 2017;6(11):2329-2341.

29. Kumari DS, Saxena N. Seed mycoflora of Lablab purpureus L. Int. J Curr. Microbiol. App. Sci 2017;6(2):1140-1144.

30. Kumari DS, Saxena N. Seed borne mycoflora of Macrotyloma uniflorum L. (Horse gram). Int. J Curr. Microbiol. App. Sci 2017;6(1):373-378.

31. Lambat A, Gadewar R, Charjan S, Dapke S, Lambat P. Study on seed quality parameters and mycoflora associated with bold and shriveled seeds of lentil. Int. J Res. in Biosci. Agric. and Tech 2015, (1).

32. Limonard T. A modified blotter test for seed health. Netherlands J. Pl. Path 1968;72:319-321.

33. Mahal Mst F. Effect of fungicide and plant extracts on seed germination and seed associated mycoflora of Lens arietinum L. and Lathyrus sativus. J Biosci. 2014;22:101102. 1023-8654.

34. Milad S, Milad AB. Seeds and their bio-control in vitro. J Humanities and Applied Sci 2017;(30).

35. Muskett AK, Malone JP. The alter method for the examination of flax seed for the presence of seed borne parasites. Am. Appl. Biol 1941;28:8-13.

36. Narayan MG, Ayodhya DK. Study of seed borne fungi of different legumes. J. Trends in Life Sci 2013;2(1):32-35.

37. Patil DP, Muley SM, Pawar PV. Control of fungi associated with green gram seeds by using Trichoderma species. Current Botany 2012;3(1):05-06.

38. Parashar R, Rizvi G, Sinha P. Seed mycoflora of some pulses collected from Bundelkhand region. J Pharmacognosy and Phytochemistry 2019;8(3):19811985.

39. Pradhan A, Lakpale N, Khare N. Effect of seed priming by seed-borne mycoflora on plant vigour of pigeonpea (Cajanus cajan (L.) Millsp.). An International Quarterly J Environmental Sciences 2015;7:403-406.

40. Pradhan K. Seed health evaluation of different varieties of Indian bean. M. Sc. (Ag.) Thesis submitted to Indira Gandhi Krishi Vishwavidyalaya, Raipur (C.G.) 2019. 
41. Pradhan K, Lakpale N. Seed health evaluation of different varieties of Indian bean by incubation method (Roll paper towel). Int. J Curr. Microbiol. App. Sci. 2020;9(5):3510-3516.

42. Pradhan S. Seed health evaluation of mung bean (Vigna radiata (L.) Wilczek) grown in agro-climatic zones of Chhattisgarh. M. Sc. (Ag.) Thesis submitted to Indira Gandhi Krishi Vishwavidyalaya, Raipur (C.G.) 2017.

43. Rahman S, Vearasilper S, Srichuwong S. Detection of seed-borne fungi in mungbean and blackgram seeds. Deutscer Tropentag in Berlin 1999.

44. Rathod LR, Jadhav MD, Mane SK, Muley SM, Deshmukh PS. Seed borne Mycoflora of legume seeds. Int. J. Adv. Biotech. Res. 2012;3(1):530-532.

45. Razia KZ, Pathak N. Evaluation of seed infection of fungi in Chickpea. J. Sci. and Tech 2013;8(2):27-36.

46. Reddy BA, Muhammad Saifulla Mallesh SB, Kumar RM. Seed mycoflora of pigeonpea and its management. Int. J Agric. Sci 2006;2(2):522-525.

47. Sadhu KA. Seed-borne fungi and their effect on seed health of green gram. Bioscience Discovery. 2014;5(2):251-255.

48. Sharma P, Singh SD, Lodha PC. Effect of fungicides on mycelia growth of seed-borne fungi of pea (Pisium sativum L.). J. Mycol. Pl. Pathol 2002;32 (3): 387.

49. Singh S, Sinha A, Kumar S, Yadav SM. Determination of seed germination percentage and effect of Trichoderma harzianum rafai on fresh and stored seed by different methods. International quarterly journal of environmental science 2014;4:181-185.

50. Sontakke NR, Hedawoo GB. Mycoflora associated with seeds of chickpea. Int. J of Life Sci. 2014;(A2):27-30.

51. Taylor Paul, Lindbeck Kurt, Chen Weidong, Ford Rebecca. Lentil Diseases. (In:) S.S. Yadav, D. McNeil, P.C. Stevenson (eds). Lentil: An ancient crop for modern times. Springer, The Netherlands 2007, 291-313.

52. Warude SN, Mane SS, Giri GK. Detection of seed borne myco-flora associated with chickpea. Int. J Pure App. Biosci 2016;4(4):309-315.

53. Yaklich RW. Rules for testing seeds. J seed tech 1985;6(2).

54. Zanjare SR, Balgude YS, Zanjare SS, Suryawanshi AV, Shelar VR. Detection of seed borne myco-flora associated with cowpea (Vigna unguiculata L. Walp). Int. J Chem. Studies 2020;8(1):1585-1587. 